\title{
Sexual development in the immature male blue fox (Alopex lagopus), investigated by testicular histology, DNA flow cytometry and measurement of plasma FSH, $\mathrm{LH}$, testosterone and soluble testicular $\mathrm{Mn}^{2+}$-dependent adenylate cyclase activity
}

\author{
A. J. Smith, M. Mondain-Monval*, K. Andersen Berg†, J. O. Gordeladze**, \\ O. P. F. Clausen $\uparrow$, P. Simon* and R. Scholler* \\ Research Farm for Furbearing Animals, Rustadveien 131, 1380 Heggedal, Norway; *Fondation de \\ Recherche en Hormonologie, 67-77 boulevard Pasteur, 94260 Fresnes, France; $\dagger$ Department of \\ Reproductive Physiology \& Pathology, The Norwegian College of Veterinary Medicine, \\ P.O. Box 8146 Dep., 0033 Oslo 1, Norway; and Departments of $\uparrow$ Pathology and \\ **Surgical Research, Rikshospitalet, Pilestredet 32,0027 Oslo 1, Norway
}

Summary. Testicular weight in young male blue foxes increased steadily from 12 weeks of age $(0.40 .7 \mathrm{~g})$ to reach peak values at the time of the mating season in March-April (5.2-6.6 g), before declining rapidly during May to low values in August at 63 weeks of age $(1 \cdot 3-1.6 \mathrm{~g})$. Primary spermatocytes were found in the spermatogenic epithelium at 20 weeks of age and by late December ( 29 weeks of age) elongated spermatids were seen. There was a good correlation between the seasonal variations in the presence of germ cell types assessed by quantitative analysis of testicular histology and the variations in numbers of haploid, diploid and tetraploid cells measured by DNA flow cytometry: no haploid cells were found before the end of November and peak numbers were observed in March.

Plasma FSH concentrations were increased from December onwards (with the exception of April). There were no clearcut seasonal variations in plasma LH concentrations although values were consistently lower in April. Testosterone concentrations were low for most of the year but increased from the end of January to the middle of April. There was no detectable seasonal variation in $\mathrm{LH}$ release in response to LHRH injection, and no typical pattern in plasma FSH concentrations during the first $100 \mathrm{~min}$ after injection. Plasma testosterone concentrations after LHRH injection rose gradually during testicular development.

There were large seasonal variations in soluble $\mathrm{Mn}^{2+}$-dependent adenylate cyclase activity in the testis, that paralleled the changes in testicular weight and haploid cell content. Values were low until December and reached a peak at the time of the mating season before falling to basal levels again by June.

The results suggest that immature male blue foxes reach full testicular development (indistinguishable from that of older animals) by the first mating season after birth, at an age of about 40 weeks.

\section{Introduction}

The blue fox is a seasonal breeder with one mating season during the year in March-April. Adult males show 5-fold annual changes in testicular volume with concurrent variations in spermatogenic 
activity which have been quantified by DNA flow cytometry (Smith et al., 1984) and testicular histology (Smith et al., 1986). Furthermore, seasonal variations occur in a wide range of plasma hormones including LH, prolactin and androgens, and in testicular FSH-binding capacity (Smith et al., 1985). Testicular redevelopment takes place over a 5-6-month period before each mating season. Limited histological and ultrastructural investigations have been performed on the seminiferous epithelium and interstitium of prepubertal blue fox testes (Andersen, 1978a, b, c; Andersen et al., 1981) but no further accounts appear to be available. Males are assumed to be fully sexually mature in their first mating season when they are about 9 months old, but there are few reports in the literature on the age of puberty in these animals.

Testicular cytosol in, among other species, the blue fox, rat and man contains a $\mathrm{Mn}^{2+}$-dependent adenylate cyclase (MnAC) believed to be associated primarily with maturing haploid cells (Gordeladze et al., 1981, 1982). The role of this enzyme is poorly understood, but it may be a precursor of the membrane-bound $\mathrm{MnAC}$ associated with spermatozoa (Braun \& Dods, 1975) and may be involved in sperm motility (Garbers \& Kopf, 1980). Annual variations in testicular content of the enzyme in the adult male blue fox follow closely the presence of haploid cells in the testis (Smith et al., 1984).

The aims of the present study were to investigate the sexual cycle of young blue fox males during the first year of life and to compare this with the annual cycle in adult males which we have previously studied.

\section{Materials and Methods}

Animals. All blue fox males were housed under natural conditions of daylength and temperature at the Research Farm for Furbearing Animals, Heggedal, Norway (latitude: $59^{\circ} 47^{\prime} \mathrm{N}$; longitude $10^{\circ} 27^{\prime} \mathrm{E}$ ) from birth in May-June 1984 to the end of the study in August 1985. The animals were within visual and olfactory contact of vixens on the farm but none was allowed to mate during the study period. The one mating season during the study (defined as the period between the first and last mating on the farm) began on 18 March 1985 and ended on 6 May 1985.

Groups of 4 blue fox males (in all 44 animals) were castrated at approximately monthly intervals under general anaesthesia from 22 August 1984 (12 weeks of age) to 15 August 1985 (63 weeks old). The animals were grouped so that there was never more than 1 cub from any litter in each group, and there was as little age difference as possible between the animals castrated on the same date (1-10 days, mean 5 days). The testes were weighed and measured, and after removing a midline section for histology (see below) the remaining tissue was cut into small pieces and immediately transferred to solid $\mathrm{CO}_{2}$ before storage at $-70^{\circ} \mathrm{C}$. The mean testicular weight for one fox castrated in October was unavailable; it was therefore calculated by regression analysis from testicular volume, since there has previously been shown to be a good correlation between these 2 measures $(y=0.74 x-0.30, r=0.93$ : Smith et al., 1984).

A group of 4 intact males was used to study plasma concentrations of LH, FSH and testosterone in response to LHRH injection (see below under 'Blood collection' for details) at monthly intervals during testicular development from September to March.

Quantitative analysis of spermatogenic activity. Midline sections of each testis were fixed for $24 \mathrm{~h}$ in Bouin's solution. The material was then stored in $70 \%$ ethanol until preparation for routine sectioning at $4 \mu \mathrm{m}$ and staining with haematoxylin and eosin.

Sections of testis from each fox were examined by light microscopy and 200 cross-sections of tubules per fox were classified into four categories according to the cellular composition of the seminiferous epithelium. The categories were the presence of (1) spermatogonia only, (2) spermatogonia and primary spermatocytes, (3) spermatogonia, spermatocytes and round spermatids and (4) spermatogonia, spermatocytes and elongated spermatids, with or without round spermatids. The normal seasonal variations in the occurrence of these categories in adult male blue foxes have been described elsewhere (Smith et al., 1986).

DNA flow cytometry. Testicular tissue stored at $-70^{\circ} \mathrm{C}$ was prepared for DNA flow cytometry as described previously (Smith et al., 1987). The relative numbers of cells with haploid (1C), diploid (2C) and tetraploid (4C) fluorescence, and in addition the population of hypofluorescent haploid cells $(<1 \mathrm{C})$, were determined from DNA histograms by planimetry. Mouse lymphocytes functioned as diploid controls. The haploid population consists of spermatids and spermatozoa, with the more mature germinal cells being found in the hypofluorescent haploid cell population $(<\mathrm{IC})$, whereas the tetraploid cells consist largely of primary spermatocytes, and the diploid cell group includes the remaining germinal cell types together with all testicular somatic cells (Smith et al., 1984). To take into account the large variations in testicular size during the study, the relative numbers (\%) of cells in each DNA population were multiplied by mean testicular weight for each fox to give arbitrary values for the numbers of cells per testis. 
Measurement of soluble $\mathrm{Mn}^{2+}$-dependent adenylate cyclase activity. Adenylate cyclase activity was measured as previously described (Gordeladze \& Hansson, 1980; Smith et al., 1984) in testicular tissue stored at $-70^{\circ} \mathrm{C}$ (available from 30 of the 44 foxes in the study). Testicular material $(\sim 100 \mathrm{mg})$ was homogenized in 10 volumes of Tris-EDTA buffer $(10 \mathrm{ml}$ Tris- $\mathrm{HCl}, 1 \mathrm{mM}-\mathrm{EDTA}, \mathrm{pH} 7 \cdot 4)$ for $2 \times 10 \mathrm{sec}$ at $0^{\circ} \mathrm{C}$. The homogenates were then filtered (pore size $100 \mu \mathrm{m}$ ) and centrifuged at $20000 \mathrm{~g}$ and $4^{\circ} \mathrm{C}$ for $30 \mathrm{~min}$. The supernatant was centrifuged further at $106000 \mathrm{~g}$ and $4^{\circ} \mathrm{C}$ for $60 \mathrm{~min}$. The supernatant from the second centrifugation was then used for assay of soluble $\mathrm{Mn}^{2+}$-dependent adenylate cyclase activity.

Aliquants $(30 \mu \mathrm{l})$ of testicular cytosol were added to $20 \mu \mathrm{l}$ incubation medium. The final assay medium contained cytosol (85-89 $\mu$ g protein), ATP $(0.7 \mathrm{mM}),\left[{ }^{32} \mathrm{P}\right]$ ATP $\left(0.8 \times 10^{6}\right.$ c.p.m. $), \mathrm{Mn}^{2+}(10 \mathrm{mM})$, cAMP $(1 \mathrm{mM}),\left[8-{ }^{3} \mathrm{H}\right] \mathrm{cAMP}$ (7300 c.p.m.), EDTA (1.4 mM) and an ATP-regenerating system providing $0.02 \mathrm{mg}$ myokinase $/ \mathrm{ml}, 0.2 \mathrm{mg}$ creatine kinase $/ \mathrm{ml}$ and $20 \mathrm{mM}$-creatine phosphate. The mixtures were incubated at $35^{\circ} \mathrm{C}$ for $20 \mathrm{~min}$ and the assay terminated by adding $100 \mu \mathrm{l}$ of a "Stop solution" containing cAMP $(10 \mathrm{mM})$, ATP $(40 \mathrm{~mm})$ and sodium dodecyl sulphate $(1 \%)$, mixing and immersing the tubes in ice. The reaction mixtures were stored at $-20^{\circ} \mathrm{C}$ until successive elution through Dowex 50-X4 and alumina oxide columns to isolate cAMP. The final eluates $(4 \mathrm{ml})$ were added to scintillation fluid $(5 \mathrm{ml})$ and counted for $10 \mathrm{~min}$.

Activities (means of duplicate determinations) were multiplied by mean testicular weight for each fox to give values for activity per testis.

Blood collection. The males were sampled before castration by using manual restraint 7 times at 20-min intervals between 09:00 and 11:20 h. In addition, 4 intact males were sampled using the same regimen on the same dates, but these were also given a rapid intravenous injection of $1 \mu \mathrm{g}$ gonadotrophin-releasing hormone (Nialutin: Novo Industry, Oslo, Norway) immediately after the second blood sample.

All blood samples $(5-10 \mathrm{ml})$ were collected in heparinized tubes. Plasma was separated by centrifugation and stored at $-20^{\circ} \mathrm{C}$ until assay.

Hormone assays. Blood samples were analysed for $\mathrm{LH}$ and testosterone using the specific radioimmunoassays previously described and validated for use in the blue fox by Møller $e t$ al. (1984). For the LH assay, the sensitivity was $0.5 \mathrm{ng} / \mathrm{ml}$ and the intra- and inter-assay coefficients of variation were $2.0 \%$ and $4.9 \%$, respectively. The corresponding values for the testosterone assay were $20 \mathrm{pg} / \mathrm{ml}, 4.9 \%$ and $11.7 \%$, respectively. Plasma concentrations of FSH were measured by a heterologous radioimmunoassay (unpublished data). This assay utilized an anti-human FSH antiserum (M91/1) donated by A. S. McNeilly, a purified canine FSH preparation (LER-1685-3A) as reference standard and a highly purified ovine FSH (LER-1976-A2) for iodination as tracer, provided by L. E. Reichert. The mean detection limit was $20 \mathrm{ng} / \mathrm{ml}$ and the intra- and inter-assay coefficients of variation were $6.0 \%$ and $10.6 \%$, respectively. All serial samples from the same animal were measured in duplicate in one assay.

Presentation of results. All values are expressed as mean \pm s.e.m. For statistical purposes, independent means were examined by Student's $t$ test. The total amounts of LH and testosterone produced during the sampling periods were assessed by calculating the areas under the release curves; in the LHRH stimulation tests, hormone release after injection of LHRH was calculated.

\section{Results}

\section{Testicular weight}

The testicular weights of the males in the study are shown in Fig. 1. Values increased steadily during the first autumn of life to reach a peak just before the mating season (6 March: $5 \cdot 2-6 \cdot 9 \mathrm{~g}$ ). At

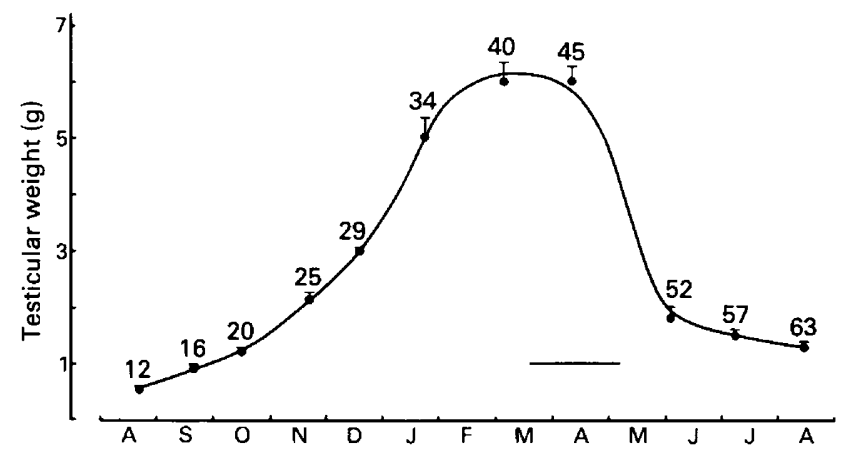

Fig. 1. Testicular weight from 12 weeks until $14 \frac{1}{2}$ months of age. Values are means (+s.e.m.) of all foxes castrated on a given date $(\mathrm{N}=4)$. The numbers above each symbol show the mean age in weeks of the foxes at castration. The horizontal bar indicates the duration of the mating season during the study, defined as the period between the first and last matings on the farm. 


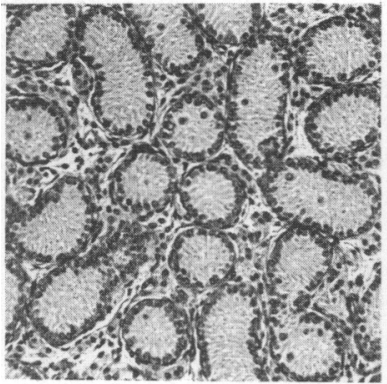

22 August

12 weeks

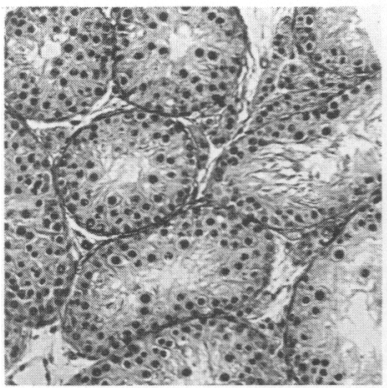

21 November

25 weeks

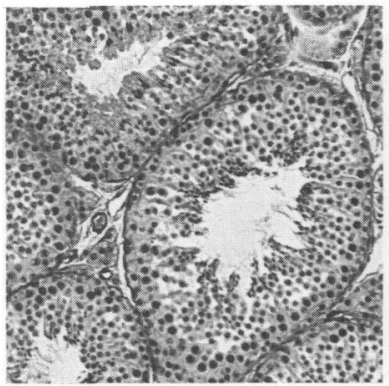

6 March

40 weeks

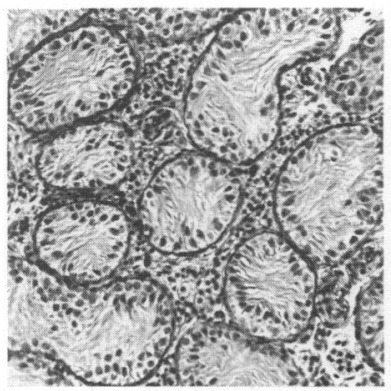

9 July

57 weeks

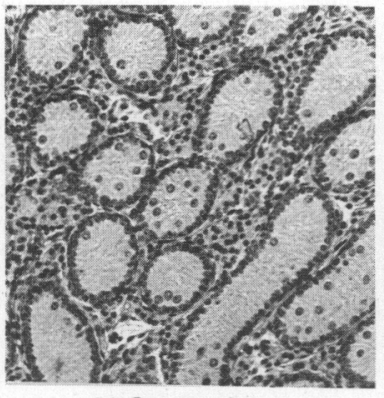

20 September

16 weeks

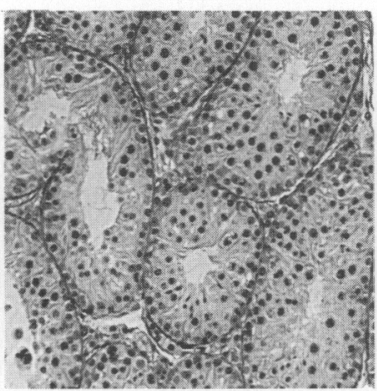

20 December

29 weeks

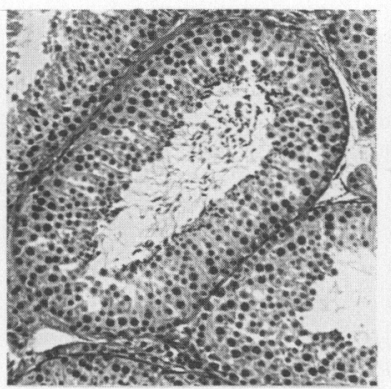

11 April

45 weeks

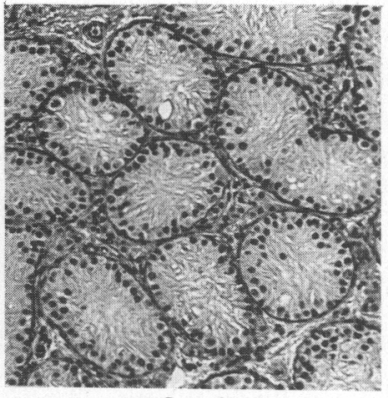

16 October

20 weeks

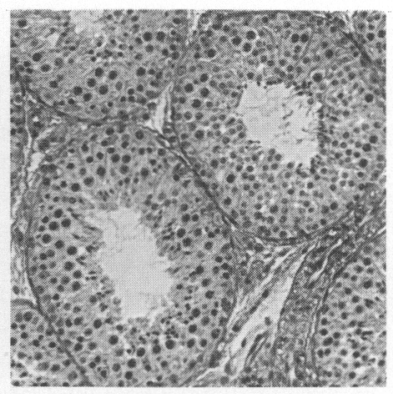

22 January

34 weeks

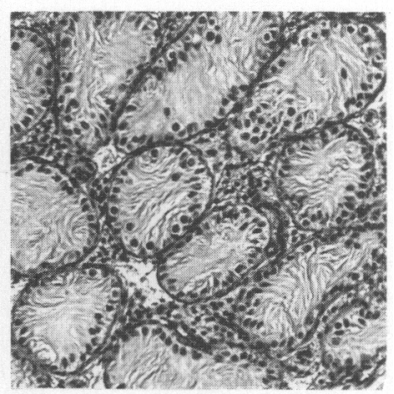

4 June

52 weeks

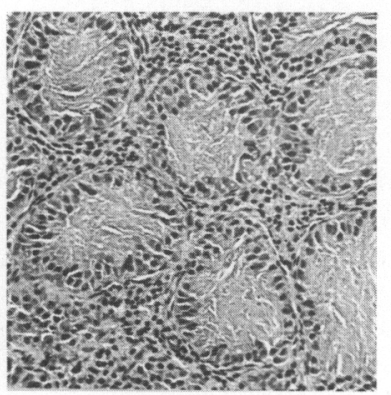

15 August

63 weeks

Fig. 2. Typical histological sections of the testis on each castration date. The age of the foxes at castration is also shown. Haematoxylin and eosin, $\times 160$. 
this time the testes were on average nearly 12 times as heavy as those from males castrated at 12 weeks of age in the beginning of the study (22 August: $0.4-0.7 \mathrm{~g}$ ). Testicular weight then declined drastically after the mating season, and in males castrated on 4 June testicular weight $(1 \cdot 4-2 \cdot 7 \mathrm{~g})$ averaged just under $30 \%$ that of males castrated on 11 April (5.3-6.6 g). Values continued to decline at a slower rate until August (63 weeks of age), when testicular weights (1.3-1.6 g) were still significantly $(P<0.01)$ higher than those observed 1 year previously at 12 weeks of age $(0.4-0.7 \mathrm{~g})$.

\section{Age-dependent changes in the histological appearance of the seminiferous tubules}

Figure 2 shows the histological appearance of the testis on each castration date. The changes in cellular composition of the seminiferous epithelium are depicted in Fig. 3(a). In August and September (at 12 and 16 weeks of age respectively) all the seminiferous tubules were of category 1 ,
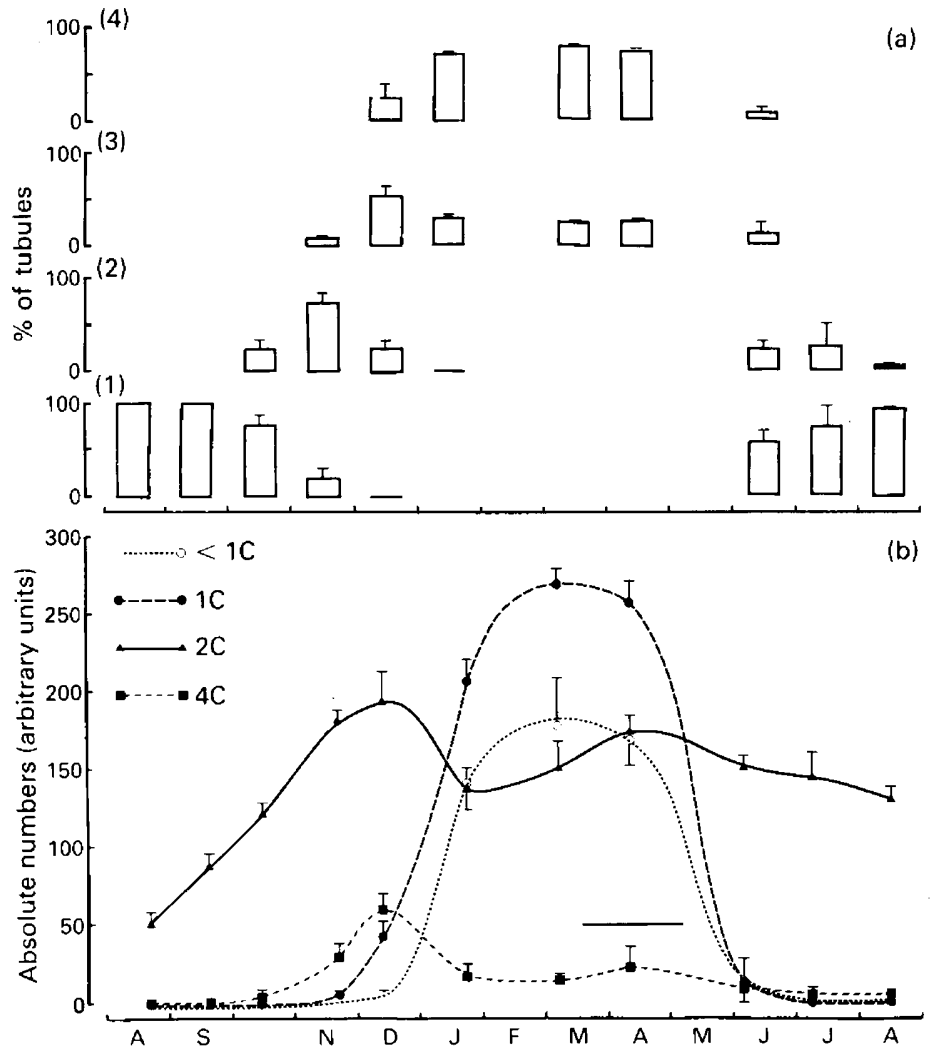

Fig. 3. Changes in (a) the relative numbers (means \pm s.e.m.) of 4 categories of seminiferous tubules and (b) the absolute numbers (arbitrary units) of haploid ( $\angle 1 \mathrm{C} \& 1 \mathrm{C}$ ), diploid (2C) and tetraploid (4C) cells in the testes of the same animals. In (a) the categories were the presence of (1) spermatogonia only, (2) spermatogonia and primary spermatocytes, (3) spermatogonia, spermatocytes and round spermatids and (4) spermatogonia, spermatocytes and elongated spermatids, with or without round spermatids. Values are means + s.e.m. of the 4 animals castrated on each occasion. The castration dates are given in Fig. 2. In (b) the values were calculated by measuring the relative numbers (\%) of each DNA category and then multiplying them by the mean testicular weight for each fox. The mating season during the study, defined as the period between the first and last matings on the farm, lasted from 18 March to 6 May and is indicated by the horizontal bar. Values are means \pm s.e.m. of 4 animals, except for October for which the results from only 3 animals were available. 
containing only spermatogonia. By October ( 20 weeks of age), $24 \%$ of tubules contained spermatogonia and primary spermatocytes. This latter category then increased to $73 \%$ by 25 weeks of age (November) and $6 \%$ of tubules also contained round spermatids. By late December ( 29 weeks), all tubular categories were represented and only $1 \%$ of tubules contained just spermatogonia while $22 \%$ were of category 2 . Nearly a quarter of tubules $(23 \%)$ were of category 4 at this time, containing elongated spermatids with or without round spermatids. In late January (at 34 weeks), the seminiferous epithelium had reached a state of almost full spermatogenic activity, with $71 \%$ of tubules in category $4,28 \%$ in category 3 and only $1 \%$ in category 2 . In March and April (40 \& 45 weeks of age, respectively), all tubules contained spermatids, with $\sim 25 \%$ in category 3 and $75 \%$ in category 4 . The onset of testicular regression was registered in early June (52 weeks of age) with all 4 tubular categories again being present. More than half of the tubules $(58 \%)$ were of category 1 while $23 \%$ were of category 2 and only $13 \%$ and $6 \%$ respectively were of categories 3 and 4 . In July (57 weeks of age) no spermatids were found; $75 \%$ of tubules were of category 1 and the remainder of category 2 . In the latter the primary spermatocytes appeared degenerate. The histological appearances of the tubules in July and August were similar, but the interstitial tissue showed a marked increase in cellularity in August.

\section{Changes in the numbers of haploid, diploid and tetraploid cells measured by DNA flow cytometry}

The variations in absolute numbers (arbitrary values) of haploid ( $<$ IC \& $1 \mathrm{C}$ ), diploid (2C) and tetraploid (4C) cells in the testis are depicted in Fig. 3(b). From August (12 weeks of age) to December ( 29 weeks), a gradual increase was seen in absolute numbers of the diploid and tetraploid cell populations (somatic cells, spermatogonia and primary spermatocytes). No haploid cells were registered before the end of November, and only one fox had more mature haploid germinal cells $(<1 C)$ in December. Numbers of diploid and tetraploid cells then declined after December and remained relatively constant until the end of the study in August. The haploid cell populations $(<1 \mathrm{C} \& 1 \mathrm{C})$, however, rose markedly during January and February, to reach peak values in early March immediately before the mating season. Haploid numbers then declined equally rapidly after the mating season and, by early June, only one fox had registrable haploid cell populations.

There were good correlations between the flow cytometric measurements and the histological results (Figs 3a \& b).

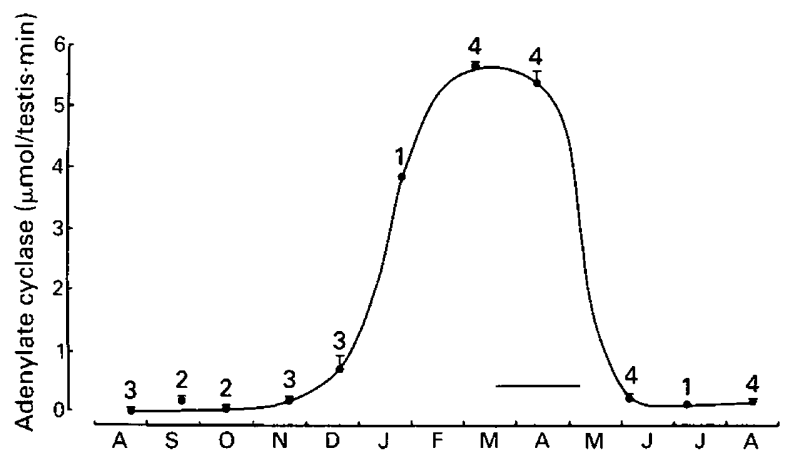

Fig. 4. Total testicular activity of the soluble $\mathrm{Mn}^{2+}$-dependent adenylate cyclase in the testes of blue foxes during the first year of life. The horizontal bar indicates the duration of the mating season during the study, defined as the period between the first and last matings on the farm. The numbers indicate the number of foxes for which values were available. Values are means + s.e.m. 

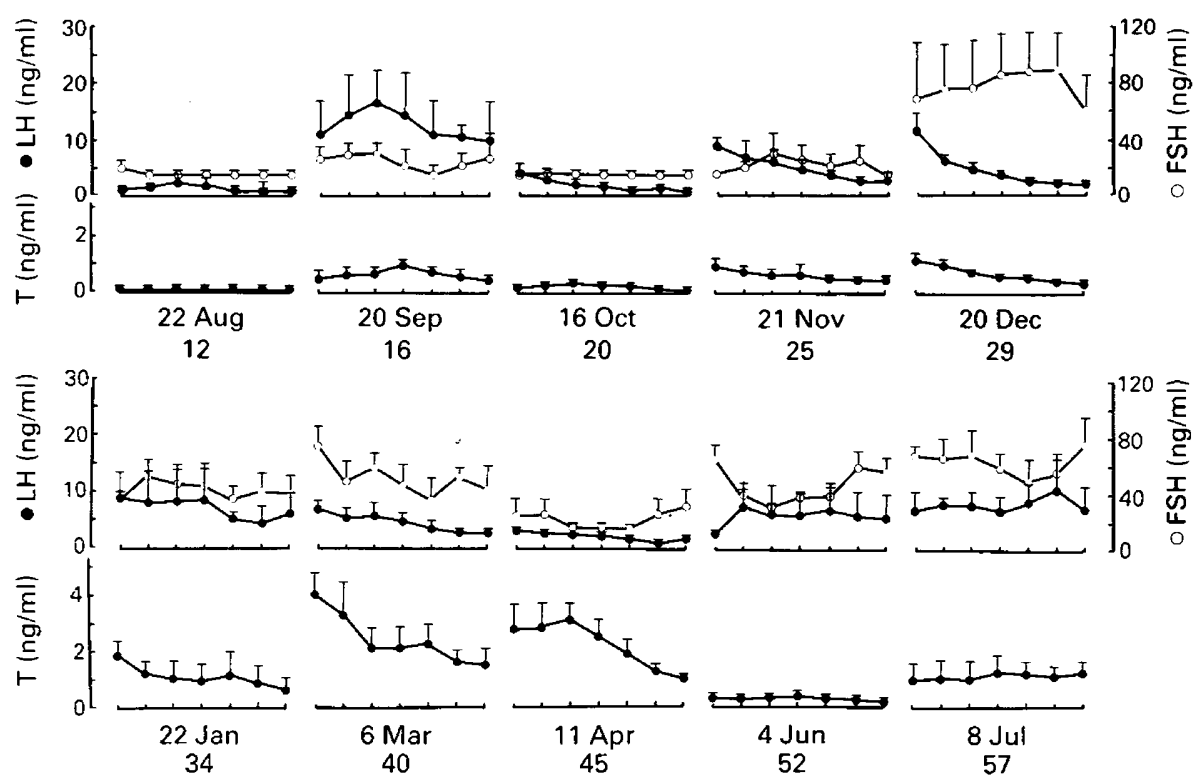

Fig. 5. Plasma concentrations (means + s.e.m.) of LH, FSH and testosterone (T) in the same groups of foxes on the day of castration (or preceding day). Seven samples were taken at 20-min intervals. The dates of castration are shown under the figures, together with the mean age (in weeks) of the foxes at the time of sampling. The mating season during the study (defined as the period between the first and last matings on the farm) was from 18 March to 6 May.

\section{Soluble $\mathrm{Mn}^{2+}$-dependent adenylate cyclase activity in the testis}

The variations in total testicular MnAC activity are shown in Fig. 4 for the 31 foxes for which results were available. Activity was low during the first autumn of life (August-November: 15-334 nmol/testis.min). Values then, however, rose rapidly to reach a peak at the time of the mating season (March-April: $4 \cdot 3-5 \cdot 8 \mu \mathrm{mol} /$ testis.min), before falling again dramatically to reach basal levels at the beginning of June. This activity was maintained until the end of the study in August (June-August: $20-676 \mathrm{nmol} /$ testis.min). Specific activity of the enzyme (not shown) also varied greatly during the study period $(1 \cdot 4-18,52 \cdot 8-72 \cdot 1$ and $0.9-16 \cdot 3 \mathrm{pmol} / \mathrm{mg}$ protein.min in August-November, March-April and June-August respectively).

\section{Variations in basal plasma gonadotrophin and steroid concentrations}

Figure 5 depicts the mean plasma concentrations of FSH, LH and testosterone in groups of 4 foxes sampled 7 times at 20-min intervals on the dates shown.

Short-term fluctuations. There were no clearcut variations in FSH concentrations over the sampling period. Concentrations of LH fluctuated in the same animal, suggesting episodic secretion, but rises in LH values could not be identified. Individual variations in testosterone concentrations were also observed: the magnitude of these variations increased during the mating season (March-April) when LH values remained lower than in other months.

Monthly variations. FSH concentrations were low from the onset of the study in August until November and only 3 of the 16 animals sampled during these months had detectable concentrations ( $>20 \mathrm{ng} / \mathrm{ml}$ : range $30-74 \mathrm{ng} / \mathrm{ml}$ ). From December onwards, however, FSH values were significantly increased $(P<0.05)$, with the exception of April when most samples had undetectable concentrations. There were no clearcut seasonal variations in LH concentrations during the study 

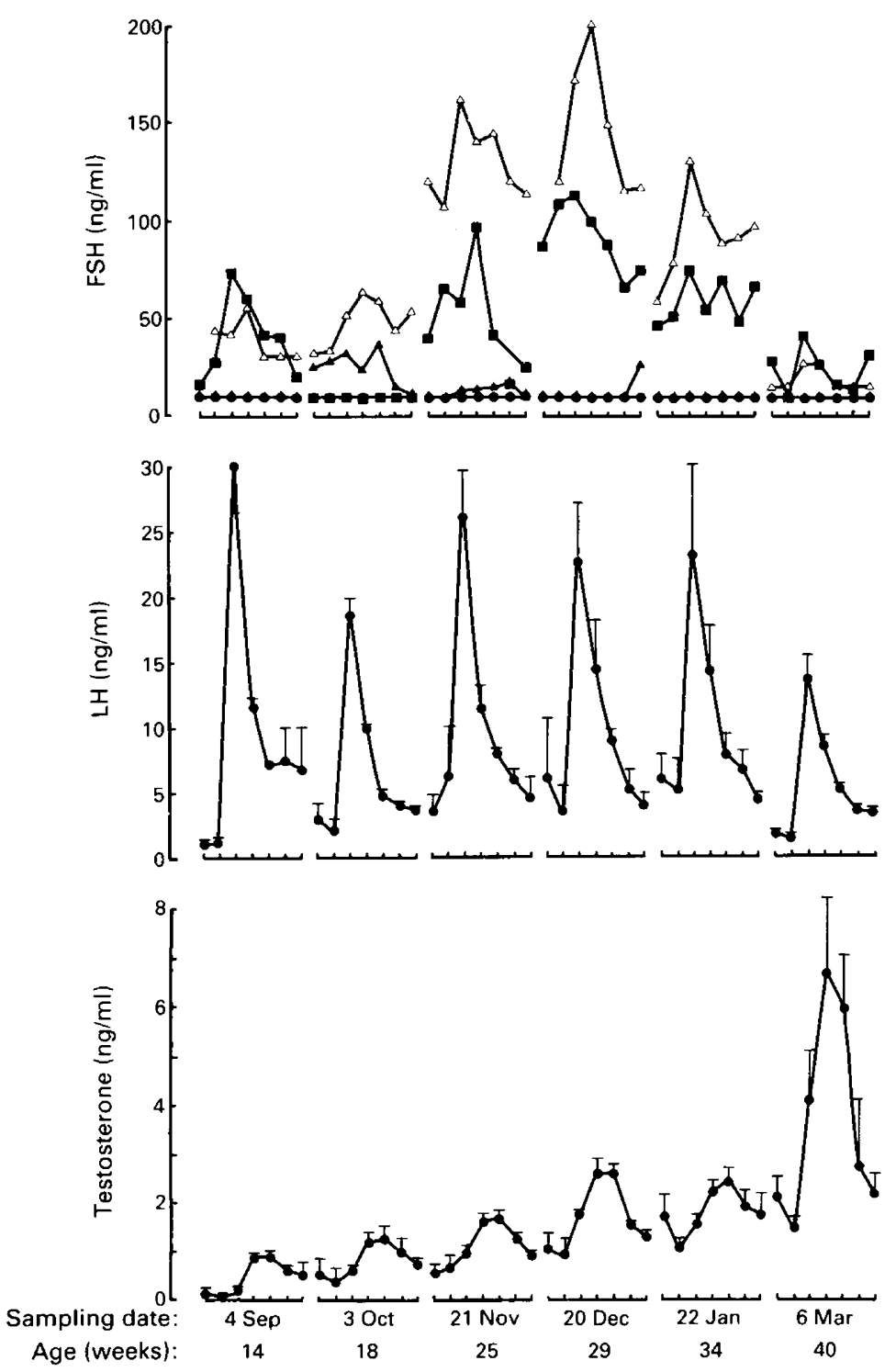

Fig. 6. Plasma concentrations of FSH (individual values), LH and testosterone (means \pm s.e.m.) before and after an intravenous injection of $1 \mu \mathrm{g} \mathrm{LHRH}$. The LHRH injection was in all cases given immediately after the second blood sample. The sampling dates and mean age of the foxes on each date are shown under the figure. The mating season during the study, defined as the period between the first and last matings on the farm, began on 18 March.

period and there were large variations between animals at all times of the year, although values were consistently lower in April $(<5.2 \mathrm{ng} / \mathrm{ml})$. Plasma testosterone concentrations reached maximum values in March and April $(0.54-5.8 \mathrm{ng} / \mathrm{ml}$, mean $2.3 \mathrm{ng} / \mathrm{ml}, n=56)$; the total release of testosterone (calculated as the areas under the curves, not shown) in these 2 months was significantly $(P<0.01)$ greater than those in August-December 1984 and June 1985. Values declined after the mating season to low concentrations in June and July $(0.02-2.9 \mathrm{ng} / \mathrm{ml}$, mean $0.7 \mathrm{ng} / \mathrm{ml}$, $n=56)$. 


\section{Variations in gonadotrophin and steroid response to LHRH stimulation}

The seasonal variations in FSH, LH and testosterone concentrations in response to LHRH injection in young male blue foxes are shown in Fig. 6. Regardless of the month, FSH concentrations remained low during the sampling period in 2 of the 4 animals and they did not increase after LHRH injection. In the other 2 foxes, basal values were increased in November, December and January and increases in FSH were detected after LHRH. There were relatively large variations in LH concentrations between individuals at all times of the year, both in terms of peak values and total release. Nevertheless, the response of LH to LHRH injection appeared to be near maximal after $20 \mathrm{~min}$ in all but one fox. In addition, the total amount of LH released in March was significantly $(P<0.05)$ less than that on the preceding sampling date and when compared with all the other months together.

Plasma testosterone concentrations after LHRH injection increased gradually during development, with a major increase immediately before the mating season on $6 \mathrm{March}$. Total release of testosterone on this date was significantly higher than on all other sampling dates $(P<0.01: 4$ September \& 3 October; $P<0.05: 21$ November, 20 December \& 22 January). Peak testosterone concentrations in March $(4 \cdot 6-10 \cdot 6 \mathrm{ng} / \mathrm{ml})$ were likewise considerably higher than those in September $(0.8-1.3 \mathrm{ng} / \mathrm{ml} ; P<0.01)$. A maximal response was observed between 40 and $60 \mathrm{~min}$ after LHRH injection, $20-40 \mathrm{~min}$ after the $\mathrm{LH}$ rise.

\section{Discussion}

The present study provides information on the sexual development of the male blue fox by means of histology, DNA flow cytometry, measurement of soluble $\mathrm{Mn}^{2+}$-dependent adenylate cyclase activity and plasma hormone measurements. The results suggest that the male blue fox reaches sexual maturity by the first mating season after birth, at an age of 40 weeks, indicating that there is no need in farm breeding programmes to differentiate between young males and animals that have previously undergone testicular development.

The good correlation between the histological and flow cytometric findings is in agreement with that previously seen in adult males (Smith et al., 1986). The first appearance of haploid cells in November and their subsequent disappearance during June coincided with the histological findings on the same dates (Figs 3a \& b). Likewise, the rise in tetraploid cell numbers in NovemberDecember mirrored the histological results. Primary spermatocytes (which are believed to constitute the majority of tetraploid cells) were not observed histologically until October, but DNA flow cytometry registered small numbers of tetraploid cells from the onset of the study. This discrepancy is probably due to the presence of tetraploid spermatogonia.

The decline in the absolute numbers of diploid and tetraploid cells observed from December (Fig. 3b) was unexpected and differs from the situation in adult males (Smith et al., 1984). One possible explanation is that the mitotic divisions during testicular development lead to an accumulation of spermatogonia and primary spermatocytes before the first meiotic division begins. Apart from this, the onset of spermatogenesis in adult and immature males appears to be very similar. The increase in the haploid cell population coincides with the increase in testicular weight (Fig. 1) and activity of the soluble $\mathrm{Mn}^{2+}$-dependent adenylate cyclase (Fig. 4) at the onset of the mating season, as previously observed in adult blue fox males (Smith et al., 1984). The 14-fold variation in total testicular activity of the adenylate cyclase enzyme was not solely due to the seasonal changes in testicular weight; specific activity of the enzyme also varied markedly during the study. Both the testicular content of the enzyme and the seasonal changes in enzyme activity noted in the present study were very similar to those previously observed in adult blue foxes studied over a 1-year period (Smith et al., 1984). The role of the $\mathrm{Mn}^{2+}$-dependent adenylate cyclase in haploid germ cells is still unclear but cyclic nucleotides, in particular cAMP, are believed to be involved in many aspects of cell function, including sperm metabolism and acquisition of sperm motility (for review see 
Sanborn et al., 1980). In studies on testicular biopsies from necrospermic and azoospermic men (Gordeladze et al., 1982) and from cryptorchid boys (Läckgren et al., 1984), soluble $\mathrm{Mn}^{2+}$ dependent adenylate cyclase activity was low or non-existent, despite the presence of haploid cells in the testis. Enzyme activity may thereffore prove to be valuable as a biological marker for the presence of functional spermatids.

Testicular regression after the first mating season was similar to that seen in older males (Smith et al., 1986), with large individual differences in the degree of regression in June. An interesting and unexplained finding was the increase in cellularity of the interstitial tissue in some parts of the testis from July to August (Fig. 2).

Plasma FSH concentrations (Figs 5 \& 6) were often below the limit of detection, which made it difficult to detect any short-term changes in hormone concentration. Despite large variations between foxes in mean basal concentrations at most times during the study, an increase in FSH was, however, detected in at least 2 of the 4 foxes sampled in December. This was associated with the increase in number of haploid cells, the rise in adenylate cyclase activity and testicular weight gain. In the adult blue fox, an FSH increase has been observed from November, associated with testicular redevelopment (unpublished data). At the time of the first breeding season (at $40-45$ weeks of age), FSH concentrations were low as in the adult male (unpublished data) when testicular development and testosterone secretion were maximal. The measurements of plasma LH concentrations (Figs 5 \& 6) also indicate a decline in hormone levels when plasma testosterone concentrations are maximal, supporting a trend previously seen in adult blue fox males (Smith et al., 1985, 1987; unpublished data). This decline in LH may be due to increased suppression by the gonads via the raised testosterone concentrations, or ' $o$ increased sensitivity of the hypothalamic-pituitary axis to negative feedback by testosterone.

There was no clear pattern of LH secretion during the prepubertal period (Figs 5 \& 6), possibly because the small number of samples obtained prevented the identification of pulsatile LH release. Nevertheless, the presence of fluctuations in basal LH concentrations from September (16 weeks of age) onwards suggests that episodic secretion may occur in young animals. Such observations have been reported for the ram (Lee et al., 1976) and human (Boyar et al., 1972) during puberty. An LH response to LHRH injection is clearly established early in puberty, well before the full development of a corresponding testosterone response (Fig. 6), as is also the case in adult males (Smith et al., 1985).

We thank Dr G. D. Niswender for the LH antiserum; Dr A. S. McNeilly for the FSH antiserum; Dr L. E. Reichert for the ovine and canine LH and FSH; and Margaret Dahl and Jostein Haugstad for skilful technical assistance.

\section{References}

Andersen, K. (1978a) Seasonal change in fine structure and function of Leydig cells in the blue fox (Alopex lagopus). Int. J. Androl. 1, 424439.

Andersen, K. (1978b) Fine structure of spermatogonia and spermatocytes in the blue fox (Alopex lagopus). Acta vet. scand. 19, 229-242.

Andersen, K. (1978c) Fine structure of developing spermatids used as a basis for staging of the spermateleosis in the blue fox (Alopex lagopus). Zentbl. VetMed. C. Anat. Histol. Embryol. 7, 164-181.

Andersen, K., Sundby, A. \& Hansson, V. (1981) Fine structure and FSH binding of Sertoli cells in the blue fox (Alopex lagopus) in different stages of reproductive activity. Int. J. Androl. 4, 570-581.

Boyar, R., Finkelstein, J., Roffwarg, H., Kapen, S.,
Weitzman, E. \& Hellman, L. (1972) Synchronization of augmented luteinizing hormone secretion with sleep during puberty. New Engl. J. Med. 287, 582-586.

Braun, T. \& Dods, R.F. (1975) Development of a $\mathrm{Mn}^{2+}$ sensitive, "soluble" adenylate cyclase in rat testis. Proc. natn. Acad. Sci. U.S.A. 72, 1097-1 101.

Garbers, D.L. \& Kopf, G.S. (1980) The regulation of spermatozoa by calcium and cyclic nucleotides. $A d v$. cyclic Nucleotide Res. 13, 251-306.

Gordeladze, J.O. \& Hansson, V. (1980) $\mathrm{Mn}^{2+}$-dependent adenylyl cyclase (AC) in rat testis: kinetic properties and optimalization of assay conditions. Int. J. Androl. 3, 539-552.

Gordeladze, J.O., Purvis, K., Clausen, O.P.F., Rommerts, 
F.F.G. \& Hansson, V. (1981) Cellular localization of the $\mathrm{Mn}^{2+}$-dependent adenylyl cyclase (AC) in rat testis. Int. J. Androl. 4, 172-182.

Gordeladze, J.O., Åbyholm, T., Cusan, L., Clausen, O.P.F. \& Hansson, V. (1982) Cellular localization of the $\mathrm{Mn}^{2+}$-dependent adenylyl cyclase $(\mathrm{AC})$ in the human testis. Archs Androl. 8, 199-204.

Läckgren, G., Gordeladze, J.O., Plöen, L. \& Hansson, V. (1984) Germ cell adenylyl cyclase activity in the human undescended testis and the effect of hCGtreatment. Archs Androl. 12, 97-102.

Lee, V.W.K., Cumming, I.A., de Kretser, D.M., Findlay, J.K., Hudson, B. \& Keogh, E.J. (1976) Regulation of gonadotrophin secretion in rams from birth to sexual maturity. I. Plasma LH, FSH and testosterone levels. J. Reprod. Fert. 46, 1-6.

Meller, O.M., Mondain-Monval, M., Smith, A., Metzger, E. \& Scholler, R. (1984) Temporal relationships between hormone concentrations and the electrical resistance of the vaginal tract of blue foxes (Alopex lagopus) at pro-oestrus and oestrus. J. Reprod. Fert. 70, $15-24$

Sanborn, B.M., Heindel, J.J. \& Robison, G.A. (1980) The role of cyclic nucleotides in reproductive processes. Ann. Rev. Physiol. 42, 37-57.
Smith, A.J., Clausen, O.P.F., Kirkhus, B., Jahnsen, T., Møller, O.M. \& Hansson, V. (1984) Seasonal changes in spermatogenesis in the blue fox (Alopex lagopus), quantified by DNA flow cytometry and measurement of soluble $\mathrm{Mn}^{2+}$-dependent adenylate cyclase activity. J. Reprod. Fert. 72, 453-461.

Smith, A.J., Mondain-Monval, M., Møller, O.M., Scholler, R. \& Hansson, V. (1985) Seasonal variations of $\mathrm{LH}$, prolactin, androstenedione, testosterone and testicular FSH binding in the blue fox (Alopex lagopus). J. Reprod. Fert. 74, $449-458$.

Smith, A.J., Bugge, H.P., Andersen Berg, K., Møller, O.M. \& Hansson, V. (1986) Seasonal changes in testicular structure and function in the blue fox (Alopex lagopus), as quantified by morphometric analysis and measurement of adenylate cyclase activity. Int. $J$. Androl. 9, 53-66.

Smith, A.J., Mondain-Monval, M., Andersen Berg, K., Simon, P., Forsberg, M., Clausen, O.P.F., Hansen, T., Møller, O.M. \& Scholler, R. (1987) Effects of melatonin implantation on spermatogenesis, the moulting cycle and plasma concentrations of melatonin, $\mathbf{L H}$, prolactin and testosterone in the male blue fox (Alopex lagopus). J. Reprod. Fert. 79, 379-390.

Received 30 March 1987 